\title{
Journal of Agrometeorology
}

ISSN : 0972-1665

Vol. No. 24 (1) : 38-41 (March 2022)

https://journal.agrimetassociation.org/index.php/jam

\section{Research Paper}

\section{Modelling of snowmelt runoff across the Himalayan Region \\ ROHITASHW KUMAR*, SAIKA MANZOOR and MAHRUKH}

College of Agricultural Engineering and Technology, Sher-e-Kashmir University of Agricultural Sciences and Technology, Srinagar, India

"Corresponding author email : rohituhf@rediffmail.com

\begin{abstract}
The Snowmelt-Runoff Model (SRM) was used to evaluate the impact of climate change on hydrological aspects of Lidder River Catchment of the Himalayan Region. It was observed that the river has an average discharge of 1082.49 cusecs. The coefficient of determination $\left(\mathrm{R}^{2}\right)$ was varies in the range 0.90-0.95 during model validation period (2013-2018). The average coefficient of determination 0.926 and average seasonal volume difference (Dv) was obtained (-) $0.83 \%$. The snow melt runoff harvested water can be used to bring 10 per cent more area under irrigation and water use efficiency which can be increased to an extent of 12-15 per cent for sustainable agriculture production in the Himalayan Region.
\end{abstract}

Key words: Climate change, runoff modelling, hydro power, Lidder catchment, snowmelt runoff

Weather influences rain fed agriculture to a considerable extent and the deficit in food production could be seen in recent years across the State of Jammu \& Kashmir due to decline in precipitation during the crop seasons (Abudu et al., 2012; Farooq et al., 2021). Apples and other horticultural crops are also suffering due to decrease in snowfall levels. Snow cover influences soil water fluxes and runoff by reducing immediate soil moisture recharge, delaying recharge by a number of days, or, in many cases, enabling soil moisture recharge prior to the beginning of the growing season. Snowmelt is a significant contributing factor to irrigation in drainage basins, so snowmelt runoff forecasts are important for watershed planning (Rashid et al., 2020). Quantification of precipitation (spatial distribution) in mountain is crucial for irrigation scheduling and high-altitude hydrology understanding (Kulkarni et al, 2002; Adam et al. 2009) for sustainable crop production. The river water budgeting snowmelt runoff is important for agricultural and allied sectors. Keeping the above in view, the study evaluated the snowmelt runoff for sustainable agricultural production in Himalayan region. The study also reflected quantification of runoff, hydrological design, and its effective utilization for sustainable agriculture.

\section{MATERIAL AND METHODS}

The Lidder watershed is located in Jhelum basin of the
Indus River. It is located between $75^{\circ} 30^{\prime} 15^{\prime \prime}$ and $75^{\circ} 45^{\prime} 15^{\prime \prime}$ longitude and $34^{\circ} 15^{\prime} 15^{\prime \prime}$ to $34^{\circ} 30^{\prime} 15^{\prime \prime}$ latitude covering an area of $768 \mathrm{~km}^{2}$. The catchment spreads over an elevation range of 1800 $5300 \mathrm{~m}$ amsl. The location map of the Lidder catchment is shown in Fig. 1. The annual precipitation recorded at Pahalgam station is illustrated in Fig. 2. Snow form of precipitation is received in winter from December to March.

\section{Snow-cover estimation}

Satellite remote sensing observations provide spatial data on snow cover at regular intervals of time which was used in the SRM (Jeelani et al., 2012). MODIS images were used for the snow cover estimation in this study. The SRM model can simulate snowmelt as a major runoff and forecast daily stream flow for river basins which can be attributed to satellite remote sensing of snow cover to cover larger basins. It uses air temperature, areal snow cover, and precipitation as input data. The SRM contains two parts in present study. The model was run basin-wise and only the mean hypsometric elevation was calculated.

\section{Input parameters}

The required inputs for this study were daily precipitation, temperature, and snow-cover, based on which discharge can be

Article info - DOI: https://doi.org/10.54386/jam.v24i1.772

Received: 12 April 2021; Accepted: 6 January 2022; Published online: 11 February 2022

This work is licenced under a Creative Common Attribution4.0International licence@Author(s),Publishing right@ Association of Agrometeorologists 
Table 1: SRM input parameters

\begin{tabular}{ll}
\hline Parameters/ factors & Values \\
\hline Degree-day & 0.5 \\
Coefficient of runoff (rain) & $0.1-0.4$ \\
Coefficient of runoff (snow) & $0.1-0.4$ (October-February) \\
& $0.5-0.7$ (March-September) \\
lapse rate of temperature & 0.44 \\
Temperature critical $\left({ }^{\circ} \mathrm{C}\right)$ & 0.8 \\
Time lag (hours) & \\
Coefficient of recession & 18 \\
X-Coefficient & \\
Y-Coefficient & 1.03 and 1.04 \\
& 0.01 and 0.03 \\
\hline
\end{tabular}

calculated. The daily precipitation and temperature data was collected from the India Meteorological Department, Rambagh. Precipitation is among the most spatially variable of meteorological variables. Weather data and observed runoff data for five years (2013-2018) was fed into the model. With the data obtained from the MODIS snow-cover products, the snow cover percentage was obtained. The data for hydrological year 2013-15 (October to September) was used for calibration while as data for hydrological year 2016-18 was used for validation of model. Runoff coefficient, degree day, rainfall area, and recession coefficients were used as input parameters (Butt and Bilal, 2011). The range of the SRM input parameters are summarized in Table 1 . The parameter values were set in the range presented in the table upon calibration of the model till the simulated runoff values were adjusted close to the observed runoff.

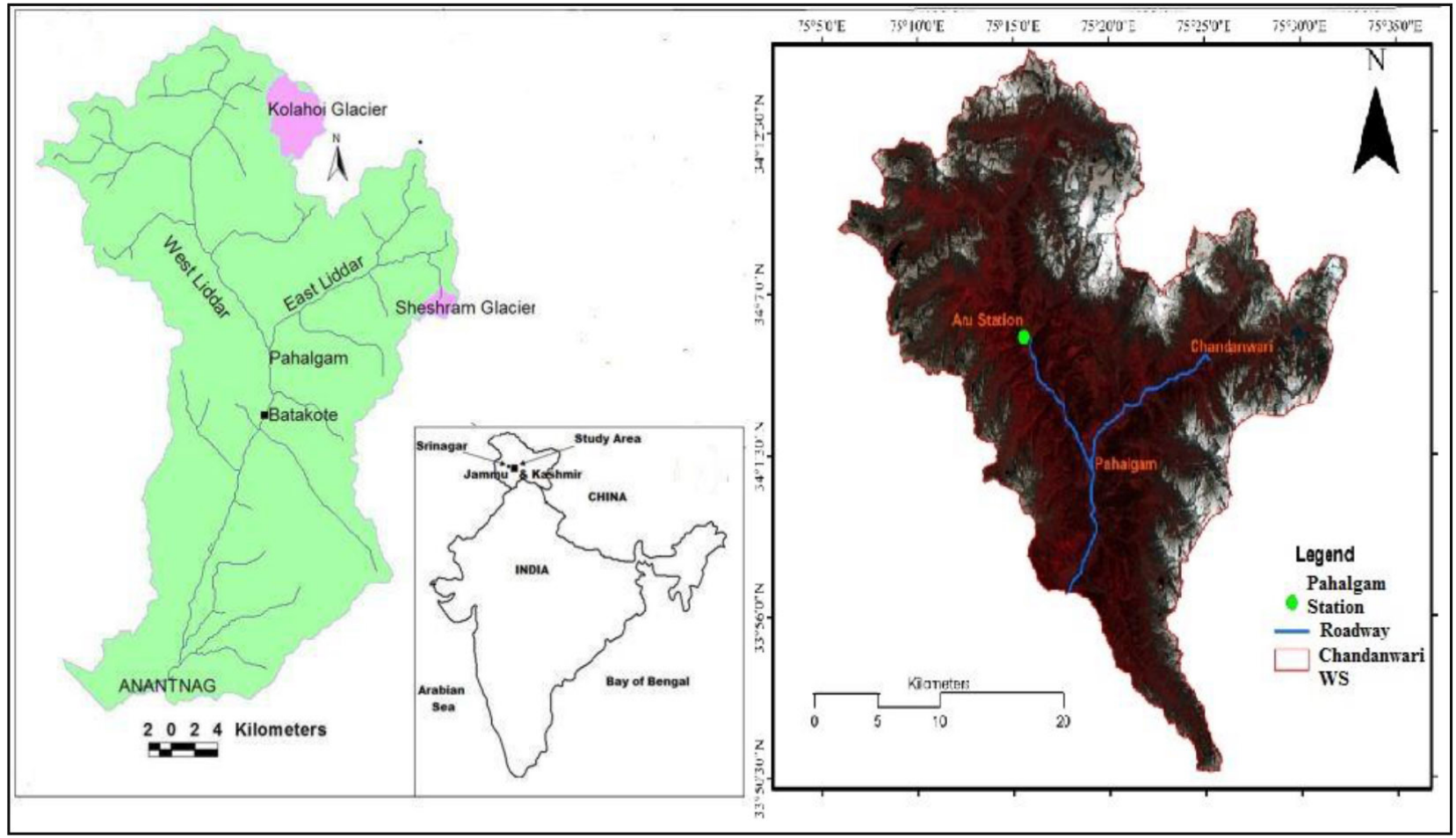

Fig. 1: Location map of the study area of Lidder watershed

\section{Model accuracy}

The SRM computer program involves the assessment of model accuracy using different accuracy criteria, the coefficient of determination $\left(\mathrm{R}^{2}\right)$ and the percent volume difference $\left(\mathrm{D}_{\mathrm{v}}\right)$ (Martinec, 2007).

$$
\mathrm{R}^{2}=1-\frac{\sum\left(\mathrm{Q}_{\mathrm{obs}}-\mathrm{Q}_{\mathrm{cal}}\right)^{2}}{\sum\left(\mathrm{Q}_{\mathrm{obs}}-\overline{\mathrm{Q}}_{\mathrm{cal}}\right)^{2}}
$$

The $\boldsymbol{D}_{\boldsymbol{v}}$ is computed as follows:

$$
\mathbf{D}_{\mathrm{v}}[\%]=\frac{\left(\mathrm{V}_{\mathbf{o b s}}-\mathrm{V}_{\mathrm{cal}}\right)}{\mathrm{V}_{\mathrm{obs}}} \times 100
$$

\section{RESULTS AND DISCUSSION}

\section{Stream-flow simulation}

The model simulated and observed discharge in different months of hydrological year 2013-15 of the Lidder basin during calibration period is shown in Fig. 3. The runoff simulations for the hydrological year 2016-18 during validation period for the different months are shown in Fig. 4. The coefficient of determination $\left(\mathrm{R}^{2}\right)$ was in the range $0.90-0.95$ for different years. While the volume difference (Dv) varied in the range of (-) 1.83 to 9.95 , with an average coefficient of determination 0.926 and average seasonal volume difference (Dv) obtained was (-) $0.83 \%$. The discharge corresponding to the time period 2013-2018 for which data on rainfall and temperature is available has been simulated with the available temporal water discharge data. The simulated discharge 


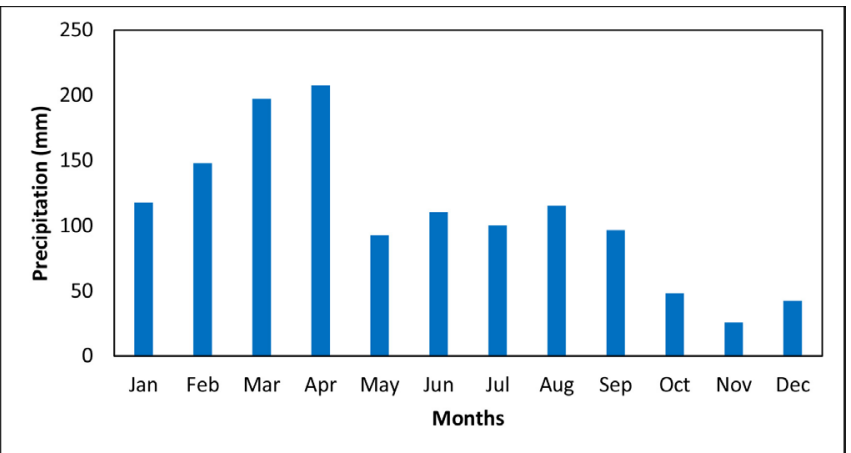

Fig. 2: Mean monthly precipitation variations in Lidder River catchment

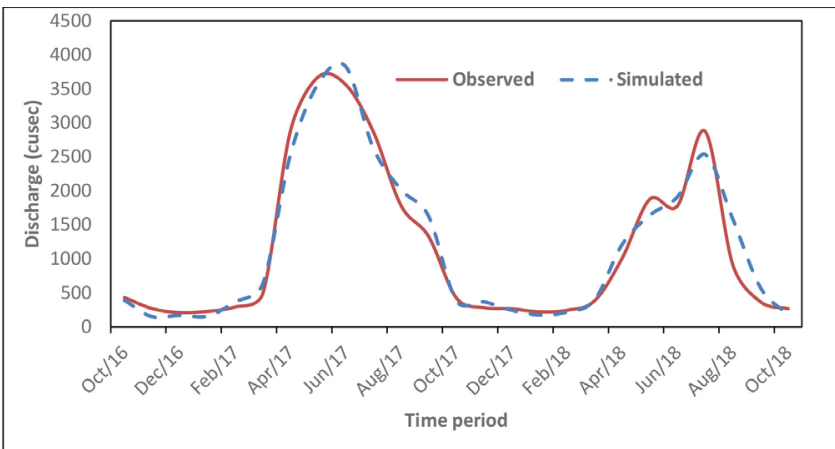

Fig, 4: Runoff simulations for the hydrological years 2016-18 of the Lidder basin

was used to construct flow duration curve for the selected study area (Fig.5). From the flow duration curve of the river it can be observed that for $50 \%$ of the total times the river has an average discharge of 1082.49 cusecs. Also beyond $95 \%$ of the total time, the flow in the river does not recede making water in the stream available all the time. The maximum runoff was yielded from catchment during the months of May-July when the river has highest discharge due to high rate of melting snow from the glaciers and snow fields.

. Growing temperature patterns can cause snow to melt sooner, impact ice formation in glacial systems, and alter runoff duration and volume. Changes in snow melt patterns may have an effect on not just the mountain's ecology and glacier landscape and agriculture development. Hydrological simulations that measure the effect of local climate change on water resources become a valuable instrument to schedule future projects as well as to estimate water releases to irrigation scheduling. Climate change and its impacts on stream flow are spatially heterogeneous. Changes to climate can affect precipitation patterns, snowfall and the persistence of snowpack. For this study area, climate change is projected to cause the months with peak stream flow to shift one month from July to June and increase the average annual flow rates which has a direct effect on the crop water use efficiency in the catchment. Having a vulnerable Himalayan ecosystem, Jammu and Kashmir is naturally changing climatic conditions because of the urbanization on a wide scale that promotes the warming trend. Environment and water resources are under risk due to climate change in the region. Due to the changing climate in the region, the decreasing streamflow in the Kashmir region might have a significant influence on water supply and demand, notably in agriculture and residential water

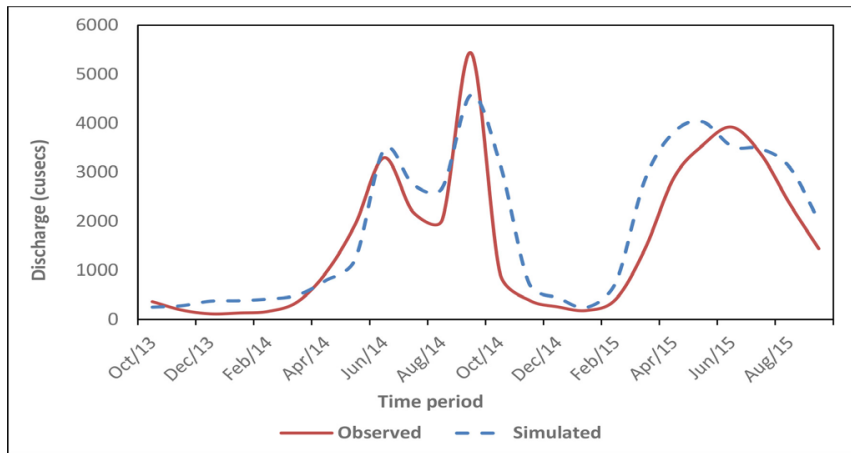

Fig. 3: Model simulated and observed discharge in different months of hydrological Year 2013-15 of the Lidder basin during calibration

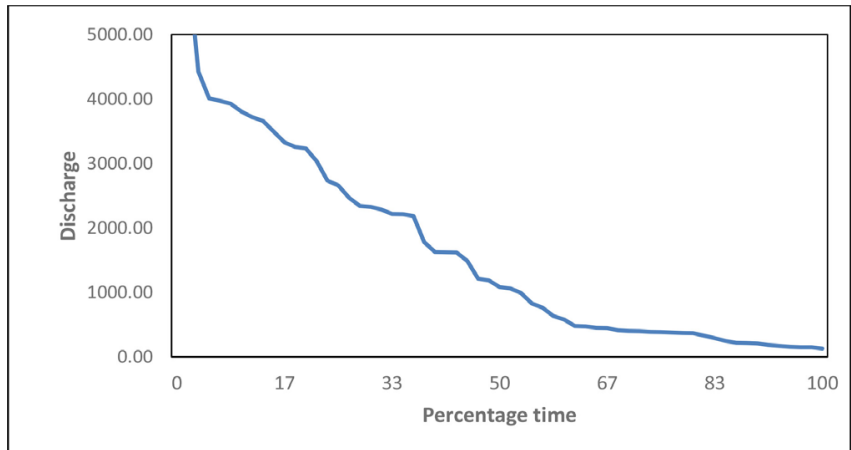

Fig. 5: Flow duration curve for the time period of 2013-2018

usage; nevertheless, it has to be thoroughly investigated. An everdeclining stream flow has contributed to substantial alterations in the Lidder watershed's downstream land system (Rashid et al., 2020). An increase in minimum temperatures might be to blame for the decrease in winter months, which is particularly evident during the winter season in the area (Romshoo et al., 2015). Anthropogenic factors, winter precipitation, and climatic warming are seen to affect the glacier's pace of shrinkage. Although certain horticultural crops are expected to be negatively affected, rangelands and livestock are likely to be benefited from this change. More irrigated land for agriculture to mitigate drought mainly water supply to paddy crop, vegetable and fruit crop during lean period in the area. Snow melt runoff can be harvested in different type of storage structure and further efficiently utilized through micro irrigation (drip and sprinkler). .

This harvested water can be used to bring $10 \%$ more area under irrigation and water use efficiency can increased about 12-15 $\%$. It can regulate stream flow, which could be benefits for irrigation. Moreover, water stored during the season for irrigation used in the dry season. Through quantification of runoff we can enhance water use efficiency for sustainable agriculture in Himalayan region. Therefore, this study is boosting irrigation for sustainable crop production in the area of water scarcity.

\section{CONCLUSION}

Owing to rapid climate change and global warming, study of snowmelt runoff is considered very important for forecasting the availability of water, its management and for planning of safe and long-term water allocations. A basin's hydrology can be determined 
using the discharge value of a basin using correct stream flow. The average coefficient of determination of 0.926 and average seasonal volume difference (Dv) of (-) $0.83 \%$ was obtained. This study also focused into the effects of climate change of the Lidder river basin on irrigation scheduling and water budgeting. The snow melt runoff harvested water can be used to bring $10 \%$ more area under irrigation and water use efficiency can increased about 12-15 $\%$. The study can be a boost to irrigation water management for sustainable crop production.

\section{ACKNOWLEDGEMENTS}

Authors are highly thankful to the ICAR-AICRP on PEASEM, College of Agricultural Engineering, SKUAST- Kashmir for providing all necessary facilities to conduct this study.

Conflict of Interest Statement: The author(s) declare(s) that there is no conflict of interest.

Disclaimer: The contents, opinions, and views expressed in the research article published in the Journal of Agrometeorology are the views of the authors and do not necessarily reflect the views of the organizations they belong to.

Publisher's Note: The periodical remains neutral with regard to jurisdictional claims in published maps and institutional affiliations.

\section{REFERENCES}

Abudu, S., Cui, C., Saydi, M., and King, J.P. (2012). Application of snowmelt runoff model (SRM) in mountainous watersheds: A review. J. Water Sci. Engg., 5(2):123-136.

Adam, J.C., Hamlet, A.F., and Lettenmaier, D.P. (2009). Implications of global climate change for snowmelt hydrology in the twenty-first century. Hydrol. Proc., 23, 962-972.

Butt,M.J.and Bilal, M. (2011).Application of snowmelt runoff model for water resource management. J. Hydrol. Proc., 25: $3735-3747$.

Farooq, Z., Kumar, R., Singh Vijay P. (2021). Trend of reference evapotranspiration under climate change in Himalayan region, India. J. Agrometeorol., 23 (1): 127-131.

Jeelani, G., Feddema, J.J., van der Veen, C.J., and Stearns, L. (2012). Role of snow and glacier melt in controlling river hydrology in Liddar watershed (western Himalaya) under current and future climate. Water Resour. Res., 48: W12508,

Kulkarni, A.V., Randhawa, S. S., Rathore, B. P., Bahuguna, I. M., and Sood, R. K. (2002). Snow and Glacier Melt Runoff Model to Estimate Hydropower Potential. J. Indian Remote Sen., 30(4), 221-228.

Martinec, J., Rango, A., and Roberts, R. (2007). Snowmelt-runoff model (SRM) user's manual. USDA Jornada Experimental Range, New Mexico State University, Las Cruces, NM 88003.

Rashid, I., Majeed, U., Aneaus, S. and Pelto, M. (2020). Linking the recent glacier retreat and depleting streamflow patterns with land system changes in Kashmir Himalaya, India. Water, 12(4), p.1168.

Romshoo, S.A., Dar, R.A., Rashid, I., Marazi, A., Ali, N. and Zaz, S.N. (2015). Implications of shrinking cryosphere under changing climate on the streamflows in the Lidder catchment in the Upper Indus Basin, India. Arc. Antar. Alpin. Res., 47(4), pp.627-644. 